\title{
Association between dietary patterns and cardiovascular risk factors in a selected population of Lower Silesia (PURE Study Poland)
}

\author{
Anna Czekajło ${ }^{1, C-D, F}$, Dorota Różańska ${ }^{1, B-D, F}$, Katarzyna Zatońska ${ }^{2, B, E-F}$, Andrzej Szuba ${ }^{3, B, E-F}$, \\ Bożena Regulska-Ilow ${ }^{1, A-B, E-F}$ \\ ${ }^{1}$ Department of Dietetics, Medical University, Wroclaw, Poland \\ ${ }^{2}$ Department of Social Medicine, Medical University, Wroclaw, Poland \\ ${ }^{3}$ Department of Angiology, Medical University, Wroclaw, Poland; Department of Internal Medicine, 4th Military Hospital, \\ Wroclaw, Poland \\ A - Research concept and design, B - Collection and/or assembly of data, C - Data analysis and interpretation, \\ $D$ - Writing the article, E - Critical revision of the article, F - Final approval of article
} Czekajło A, Różańska D, Zatońska K, Szuba A, Regulska-llow B. Association between dietary patterns and cardiovascular risk factors in
a selected population of Lower Silesia (PURE Study Poland). Ann Agric Env Med. 2018; 25(4): 635-641. doi: 10.26444/aaem/76321

\begin{abstract}
Introduction. Dietary pattern analysis is used to describe the dietary habits of a selected population. In many studies, dietary patterns (DPs) have been associated with risk factors for cardiovascular disease (CVD). The aim of the study was to assess the association between dietary patterns identified in the population of Lower Silesia, Poland, with anthropometric and biochemical risk factors for CVD.

Materials and method. The study group included 2,025 participants of the Prospective Urban Rural Epidemiological (PURE) Study. Dietary intake was evaluated based on data from the Food Frequency Questionnaire (FFQ). Dietary patterns were derived using principal component analysis (PCA). The relationship between DPs and body mass index (BMI), waist circumference, waist-hip ratio, blood pressure, total cholesterol, HDL cholesterol, LDL cholesterol, triglycerides and fasting glucose level, was assessed.

Results. Three dietary patterns identified in the study explained $35.6 \%$ of total variance. The 'fruit, vegetables \& dairy' DP, characterized by a high intake of vegetables, fruits, nuts, seeds, raisins, milk and low-fat dairy, was associated with improved lipid profile and anthropometric measures, lower diastolic blood pressure and lower fasting glucose concentration. 'Traditional' and 'fat \& sugar' DPs were unfavourably associated with most of the risk factors for CVD presented in this study. Conclusions. Dietary patterns identified in this study were differently related to selected anthropometric and biochemical risk factors for CVD. 'Fruit, vegetables \& dairy' DP was favourably associated with the biochemical and anthropometric CVD risk factors, and was characterized by higher nutritional value in comparison with 'traditional' and 'fat \& sugar' DPs.
\end{abstract}

Key words

risk factors, cardiovascular diseases, principal component analysis, dietary patterns

\section{INTRODUCTION}

Cardiovascular disease (CVD) is a major cause of death in Europe and worldwide. Although in years 2003-2013 the mortality rate from CVD has decreased in Poland by $23.9 \%$ among men and $26.5 \%$ among women, cardiovascular diseases were responsible for $49 \%$ of deaths in Poland in $2014[1]$.

The CVD risk factors have been identified for the first time in the Framingham Heart Study. Factors associated with the higher risk of CVD development were: elevated level of total cholesterol (TC), low-density lipoprotein cholesterol (LDL-C) and triglycerides (TG), reduced level of high-density lipoprotein cholesterol (HDL-C), high blood pressure, overweight and obesity, cigarette smoking, low physical activity, age, male sex and genetic factors [2].

The prevalence of the risk factors for CVD in Poland has changed over the years. Based on the data from the NATPOL 2011, the prevalence of hypertension increased by

Address for correspondence: Dorota Różańska, Department of Dietetics, Medical University, Wroclaw, Poland

e-mail: dorota.rozanska@umed.wroc.pl)

Received: 14.06.2017; accepted: 07.08.2017; first published: 03.10.2017
$2 \%$ compared to 2002 (32\% vs. 30\%), the prevalence of obesity - by $3 \%$ (22\% vs. $19 \%)$ and the prevalence of diabetes - by $1 \%$ ( $5 \%$ vs. $4 \%$ ). The prevalence of hypercholesterolaemia (TC $\geq 190 \mathrm{mg} / \mathrm{dl})$ decreased by $9 \%$ (61\% vs. $70 \%$ ) [3]. The percentage of people reporting heart or circulation problems in Poland is currently the highest in Europe [1].

Proper diet plays a dual role in prevention of CVD as both independent risk factor and agent modifying other factors [4-7]. Dietary habits considered as the most unhealthy comprise: excessive intake of energy, sodium, saturated fatty acids (SFA), trans-unsaturated fatty acids and added sugar. Inversely, consumption of fruits, vegetables, legumes, nuts, whole grains and fish, as well as moderate consumption of alcohol, is recommended [8].

Due to the complexity of the diet and interactions between products and nutrients, current guidelines pay detailed attention to the synergistic effect of consumed foods on health. This rather new approach is called dietary pattern analysis. Dietary patterns (DPs) are defined as the quantities, variety, proportions and combinations of food products and beverages, as well as the frequency of their consumption. Dietary pattern analysis can be used to describe the association between habitual diet and various health outcomes [9]. 


\section{OBJECTIVE}

The aim of the study was to assess the relationship of dietary patterns identified in the middle-age population of Lower Silesia with anthropometric and biochemical risk factors for cardiovascular diseases.

\section{MATERIALS AND METHOD}

Study population. The study group included 2,025 adults (1276 women and 749 men) who were enrolled in the Polish section of the Prospective Urban Rural Epidemiological (PURE) Study. All subjects were volunteers and signed an informed consent form. Participants lived in the urban or rural areas of Lower Silesian Province in Poland. The inclusion criteria was a permanent place of residence and age between 35-70 years. The study was approved by the Polish Ethics Committee (No. KB-443/2006) and performed in the years 2007-2009.

The PURE Study is an international prospective cohort study which involving 153,996 adults from 17 countries, classified as low, middle or high income. The aim of the PURE Study is to explain the reasons for the increased incidence of non-communicable diseases in countries with various levels of development. The methodology and main results of the PURE Study have been published previously $[10,11]$.

Measurement of cardiovascular risk factors. Blood glucose, triglycerides, total cholesterol, HDL cholesterol and LDL cholesterol levels were measured in venous blood samples. HDL-C and TG concentration were measured using the enzymatic assay SPINREACT (Sant Esteve De Bas, Girona, Spain). LDL-C was calculated among participants with a TG concentration lower than $400 \mathrm{mg} / \mathrm{dl}$ based on the Friedewald formula (LDL-C = TC - HDL-C - TG/5). TC, HDL-C and TG concentration were analyzed for 738 men and 1,258 women, while LDL-C was analyzed for 725 men and 1,250 women. Blood glucose level was tested after an overnight fast for 592 men and 1,045 women, using the Ascensia Entrust Glucometer (Bayer, Germany). All serum lipids were expressed in $\mathrm{mmol} / \mathrm{l}$ while fasting blood glucose concentration was expressed in $\mathrm{mg} / \mathrm{dl}$.

Systolic and diastolic blood pressure were measured for 744 men and 1,268 women using a certified digital sphygmomanometer (Omron HEM-711 IntelliSense, Tokyo, Japan) and expressed in $\mathrm{mmHg}$. Patients were instructed to rest for 5 minutes before blood pressure measurement. In the analyzes were included the average values of blood pressure measured twice in each participant.

Body height $(\mathrm{H})$ was measured without shoes, with an accuracy of $0.5 \mathrm{~cm}$ using a stadiometer. Body weight (W) was measured without shoes and outer garments, using a calibrated scale with an accuracy of $0.1 \mathrm{~kg}$. Body mass index (BMI) was calculated based on the weight in kilograms and height in meters according to the formula: $\mathrm{BMI}=\mathrm{W}(\mathrm{kg}) / \mathrm{H}^{2}\left(\mathrm{~m}^{2}\right)$. Waist circumference was measured in the middle-point between the lowest rib and the iliac crest and expressed in centimeters with $0.5 \mathrm{~cm}$ precision. Hip circumference was measured at the widest lateral extension of the hips and also expressed in centimeters with $0.5 \mathrm{~cm}$ precision. Waist-hip ratio (WHR) was calculated by dividing the waist circumference by the hip circumference. BMI and waist circumference were analyzed for 749 men and 1,276 women, and WHR was analyzed for 748 men and 1,273 women.

Dietary assessment. Dietary intake was assessed based on data from the Food Frequency Questionnaire (FFQ) validated for the population aged 35-70 years of Lower Silesian Province [12]. The FFQ consists of 154 food items classified into 8 groups: milk and dairy products, fruits, vegetables, meat and eggs, cereal products, mixed dishes, beverages and snacks. Frequency of consumption was recorded in 9 categories: 'never or less than once a month', ' $1-3$ times a month', 'once a week', '2 - 4 times a week', '5 - 6 times a week', 'once a day', ' 2 - 3 times a day', ' 4 - 5 times a day', 'more than 6 times a day'. The portion sizes of the consumed foods, e.g. glass of juice, spoon of mayonnaise or slice of bread, were determined using the Album of Photographs of Food Products and Dishes [13]. Dietary interview included the one year period before the study. The average content of macronutrients, vitamins and minerals in analyzed diets was determined using database of the US Department of Agriculture and Polish Food Composition Tables [14, 15].

Dietary patterns identification. In order to identify the dietary patterns in the study group, food items from the FFQ were classified into 24 groups: 1) milk and low fat dairy, 2) high-fat cheese and cream, 3) fats, 4) chips, 5) potatoes, 6) eggs, 7) red meat, 8) processed meat, 9) low fat and unprocessed poultry, 10) high fat and processed poultry, 11) fish, 12) unrefined grains, 13) refined grains, 14) mixed dishes, 15) soups, 16) alcohol, 17) sweets, 18) sweetened beverages, 19) sugar and honey, 20) nuts, seeds and raisins, 21) fruits, 22) juices, 23) cooked vegetables and 24) raw vegetables. The main criterion for inclusion of the food product in the group was its composition and nutritional value. Products that do not provide any energy, such as unsweetened coffee and tea, were excluded from the analysis. Characteristics of the food groups is presented in Table 1.

Dietary patterns were identified $a$ posteriori using principal component analysis (PCA) with varimax rotation. Six factors had eigen values $\geq 1$ (the Kaiser's criterion); however, based on the Scree plot and interpretability of derived factors, 3 dietary patterns were determined in the final analysis. Values of a factor loadings higher than 0.5 were accepted as the cut-off point.

Statistical analysis. All statistical analyses were conducted using Statistica software version 12.0 PL (Statsoft Inc., USA). For each dietary pattern, the study participants were divided into 4 groups (quartiles), based on the factor scores of their diet. Mean values of age, cholesterol, triglycerides and fasting blood glucose level, blood pressure, waist circumference, WHR and BMI, as well as selected nutrients content in the diet, were calculated for each quartile of derived DPs. Due to the differences in the normal values of HDL-C, waist circumference and WHR, those variables were calculated separately for both male and female individuals. Selected nutrients intake was calculated per $1,000 \mathrm{kcal}$ because higher energy intake is usually associated with the increased macronutrients content in the diet. Differences between quartiles of DPs were calculated using the Kruskal-Wallis test. The level of statistical significance for all analyses was set at $\alpha=0.05$. 
Table 1. Characteristics of food groups

\begin{tabular}{|c|c|}
\hline Food group & Products \\
\hline Milk and low-fat dairy & $\begin{array}{l}\text { low-fat milk, milk, buttermilk, cocoa with milk, } \\
\text { cottage cheese, quark, low-fat yoghurt, yogurt, kefir }\end{array}$ \\
\hline High-fat cheese and cream & Feta cheese, hard cheese, cheese "fromage", cream \\
\hline Fats & butter, lard, margarine, mixed fat, mayonnaise \\
\hline Chips & chips \\
\hline Potatoes & potatoes \\
\hline Eggs & eggs \\
\hline Red meat & $\begin{array}{l}\text { beef steaks, pork cutlets, organ meat, boiled pork, } \\
\text { beef and pork cutlets }\end{array}$ \\
\hline $\begin{array}{l}\text { Processed meat and } \\
\text { poultry }\end{array}$ & $\begin{array}{l}\text { ham, frankfurter, luncheon meat, sausages, head } \\
\text { cheese, tinned chicken pate }\end{array}$ \\
\hline Low-fat poultry & boiled chicken (skinless), roast turkey \\
\hline High-fat poultry & chicken fillets, fried chicken \\
\hline Fish & cod fillets, smoked mackerel, herring \\
\hline Unrefined grains & $\begin{array}{l}\text { wheat-rye bread, pasta, buckwheat groats, pearl } \\
\text { barley groats, porridge }\end{array}$ \\
\hline Refined grains & wheat bread and rolls, rice, cornflakes \\
\hline Mixed dishes & $\begin{array}{l}\text { baked beans with meat, stuffed cabbage leaves, } \\
\text { dumplings, sauerkraut with sausage and meat, } \\
\text { vegetable salad }\end{array}$ \\
\hline Soups & vegetable soups, broth \\
\hline Alcohol & beer, red wine, vodka \\
\hline Sweets & cakes, cookies, chocolate, halva, drops \\
\hline Beverages & fruit drinks, soft drinks \\
\hline Sugar and honey & sugar, honey \\
\hline Nuts, seeds and raisins & walnuts and other nuts, seeds, raisins \\
\hline Fruits & fruits \\
\hline Juices & fruit juices, carrot juice \\
\hline Cooked vegetables & $\begin{array}{l}\text { cooked vegetables, tomato sauce, canned sweet } \\
\text { corn, canned peas }\end{array}$ \\
\hline Raw vegetables & raw vegetables \\
\hline
\end{tabular}

Table 2. General characteristics of the study group

\begin{tabular}{|c|c|c|c|c|c|}
\hline \multirow{2}{*}{ Variable } & \multicolumn{2}{|r|}{ Males } & \multicolumn{2}{|r|}{ Females } & \multirow{2}{*}{$P$} \\
\hline & $n$ & $X \pm S D$ & $n$ & $X \pm S D$ & \\
\hline Age, years & 749 & $54.3 \pm 10.0$ & 1276 & $54.6 \pm 9.7$ & Ns \\
\hline $\mathrm{BMI}, \mathrm{kg} / \mathrm{m}^{2}$ & 749 & $28.5 \pm 4.5$ & 1276 & $27.9 \pm 5.4$ & 0.0004 \\
\hline Waist circumference, cm & 749 & $99.3 \pm 12.4$ & 1276 & $88.4 \pm 13.6$ & $<0.0001$ \\
\hline WHR & 748 & $0.96 \pm 0.07$ & 1273 & $0.84 \pm 0.08$ & $<0.0001$ \\
\hline $\begin{array}{l}\text { Systolic blood pressure, } \\
\mathrm{mmHg}\end{array}$ & 744 & $150.9 \pm 20.1$ & 1268 & $142.0 \pm 21.6$ & $<0.0001$ \\
\hline $\begin{array}{l}\text { Diastolic blood pressure, } \\
\mathrm{mmHg}\end{array}$ & 744 & $89.1 \pm 11.6$ & 1268 & $84.2 \pm 10.9$ & $<0.0001$ \\
\hline $\mathrm{TC}, \mathrm{mmol} / \mathrm{I}$ & 738 & $4.99 \pm 1.05$ & 1258 & $5.13 \pm 0.99$ & 0.0003 \\
\hline $\mathrm{HDL}-\mathrm{C}, \mathrm{mmol} / \mathrm{l}$ & 738 & $1.34 \pm 0.38$ & 1258 & $1.60 \pm 0.40$ & $<0.0001$ \\
\hline LDL-C, mmol/l & 725 & $2.93 \pm 0.90$ & 1250 & $2.91 \pm 0.93$ & Ns \\
\hline $\mathrm{TG}, \mathrm{mmol} / \mathrm{l}$ & 738 & $1.62 \pm 1.12$ & 1258 & $1.37 \pm 0.82$ & $<0.0001$ \\
\hline Fasting glucose, mg/dl & 592 & $101.41 \pm 24.41$ & 1045 & $98.81 \pm 20.38$ & 0.0230 \\
\hline
\end{tabular}

\section{RESULTS}

Table 2 illustrates the sample characteristics, stratified by gender. The mean age of the study participants was similar in the group of men (54.3 \pm 10.0 years) and women $(54.6 \pm 9.7$ years). The mean BMI, waist circumference, WHR, systolic and diastolic blood pressure, HDL-C, TG and fasting glucose concentration in blood were significantly higher in the group of men compared to women. Inversely, TC was significantly higher in the group of women in comparison with men. No difference in LDL-C was found between gender groups.

Three dietary patterns identified in PCA explained 35.6\% of total variance. The first DP was characterized by high factor loadings of mixed dishes (0.70), red meat (0.67), soups (0.61), processed meat (0.61) and fish (0.58), and accounted for $19.3 \%$ of variance. Due to the frequent consumption of these products in the typical Polish diet, this pattern was called 'traditional'. The second DP in the analysis was associated with higher factor loadings of raw vegetables (0.73), fruits (0.71), cooked vegetables (0.66), nuts, seeds and raisins (0.58) and milk and low-fat dairy (0.51). It explained $10.5 \%$ of variance and was called the 'fruit, vegetables \& dairy' DP. The third DP, called 'fat \& sugar", characterized by high factor loadings of fats (0.67), sugar and honey (0.59), sweets (0.58), refined grains (0.58) and high-fat cheese and cream (0.57), and explained $5.8 \%$ of variance. The factor-loading matrix for the dietary patterns is presented in Table 3.

Table 3. Factor-loading matrix for identified dietary patterns ${ }^{\mathrm{a}}$

\begin{tabular}{|c|c|c|c|}
\hline Variable & $\begin{array}{l}\text { "Traditional" } \\
\text { DP }\end{array}$ & $\begin{array}{c}\text { "Fruit, vegetables } \\
\text { \& dairy" DP }\end{array}$ & $\begin{array}{c}{ }_{\text {"Fat \& sugar" }} \\
\text { DP }\end{array}$ \\
\hline Mixed dishes & 0.70 & & \\
\hline Red meat & 0.67 & & 0.29 \\
\hline Soups & 0.61 & 0.26 & \\
\hline Processed meat & 0.61 & & 0.47 \\
\hline Fish & 0.58 & & \\
\hline Low-fat poultry & 0.48 & & \\
\hline High-fat poultry & 0.44 & 0.31 & \\
\hline Alcohol & 0.26 & & \\
\hline Raw vegetables & 0.23 & 0.73 & \\
\hline Fruits & & 0.71 & \\
\hline Cooked vegetables & 0.39 & 0.66 & \\
\hline Nuts, seeds and raisins & & 0.58 & \\
\hline Milk and low-fat dairy & & 0.51 & 0.25 \\
\hline Unrefined grains & & 0.40 & \\
\hline \multicolumn{4}{|l|}{ Beverages } \\
\hline Fats & & & 0.67 \\
\hline Sugar and honey & & & 0.59 \\
\hline Sweets & & 0.20 & 0.58 \\
\hline Refined grains & 0.26 & & 0.58 \\
\hline High-fat cheese and cream & & 0.28 & 0.57 \\
\hline Chips & 0.31 & & 0.39 \\
\hline Eggs & 0.24 & & 0.32 \\
\hline Juices & 0.20 & & 0.32 \\
\hline Potatoes & & & 0.22 \\
\hline
\end{tabular}

a - absolute values of factor loadings $<0.2$ not shown; absolute values of factor loadings $\geq 0.5$ in bold; DP - dietary pattern 
Tables 4, 5 and 6 show the characteristics of anthropometric and biochemical CVD risk factors in quartiles of dietary patterns. Compared to participants in the lowest quartile of the 'traditional' dietary pattern, participants in the highest quartile had significantly higher diastolic blood pressure, waist circumference, WHR, BMI, TG and fasting glucose level. Moreover, women in Q4 had significantly lower HDL-C than women in Q1 of the 'traditional' DP. Inversely, subjects in the upper quartile of 'fruit, vegetables \& dairy' DP, despite

Table 4. Characteristics of CVD risk factors by quartiles of "traditional" dietary pattern $(X \pm S D)$

\begin{tabular}{|c|c|c|c|c|c|}
\hline \multirow{2}{*}{\multicolumn{2}{|c|}{ Variable }} & \multicolumn{4}{|c|}{ "Traditional" DP } \\
\hline & & Q1 & Q2 & Q3 & Q4 \\
\hline \multicolumn{2}{|l|}{ Age, years } & $54.8 \pm 9.5$ & $54.7 \pm 9.8$ & $54.2 \pm 10.3$ & $54.5 \pm 9.6$ \\
\hline \multicolumn{2}{|c|}{$\begin{array}{l}\text { Systolic blood pressure, } \\
\mathrm{mmHg}\end{array}$} & $144.5 \pm 20.5$ & $145.4 \pm 21.5$ & $144.3 \pm 22.3$ & $146.9 \pm 21.6$ \\
\hline \multicolumn{2}{|c|}{$\begin{array}{l}\text { Diastolic blood pressure, } \\
\mathrm{mmHg}\end{array}$} & $84.9 \pm 10.5$ & $85.9 \pm 11.6$ & $85.6 \pm 11.4$ & $87.4 \pm 12.1^{\mathrm{a}}$ \\
\hline \multirow{2}{*}{$\begin{array}{l}\text { Waist } \\
\text { circumference, } \\
\mathrm{cm}\end{array}$} & Females & $84.5 \pm 12.3$ & $88.0 \pm 12.8$ & $90.1 \pm 13.4$ & $92.1 \pm 14.9^{a}$ \\
\hline & Males & $97.9 \pm 11.6$ & $99.4 \pm 11.1$ & $97.5 \pm 12.1$ & $101.4 \pm 13.5^{\mathrm{a}}$ \\
\hline \multirow{2}{*}{ WHR } & Females & $0.82 \pm 0.06$ & $0.84 \pm 0.08$ & $0.85 \pm 0.08$ & $0.86 \pm 0.08^{\mathrm{a}}$ \\
\hline & Males & $0.95 \pm 0.07$ & $0.97 \pm 0.07$ & $0.96 \pm 0.08$ & $0.97 \pm 0.07^{\mathrm{a}}$ \\
\hline \multicolumn{2}{|l|}{$\mathrm{BMI}, \mathrm{kg} / \mathrm{m}^{2}$} & $27.2 \pm 5.0$ & $28.0 \pm 5.0$ & $28.2 \pm 4.9$ & $29.1 \pm 5.3^{\mathrm{a}}$ \\
\hline \multicolumn{2}{|l|}{$\mathrm{TC}, \mathrm{mmol} / \mathrm{l}$} & $5.05 \pm 0.98$ & $5.03 \pm 0.99$ & $5.08 \pm 0.98$ & $5.16 \pm 1.1$ \\
\hline \multirow{2}{*}{$\mathrm{HDL}-\mathrm{C}, \mathrm{mmol} / \mathrm{l}$} & Females & $1.63 \pm 0.38$ & $1.62 \pm 0.40$ & $1.57 \pm 0.42$ & $1.58 \pm 0.40^{\mathrm{a}}$ \\
\hline & Males & $1.33 \pm 0.33$ & $1.35 \pm 0.48$ & $1.37 \pm 0.34$ & $1.32 \pm 0.36$ \\
\hline \multicolumn{2}{|l|}{ LDL-C, mmol/I } & $2.91 \pm 0.90$ & $2.86 \pm 0.92$ & $2.92 \pm 0.93$ & $2.99 \pm 0.93$ \\
\hline \multicolumn{2}{|l|}{$\mathrm{TG}, \mathrm{mmol} / \mathrm{l}$} & $1.34 \pm 0.76$ & $1.41 \pm 0.84$ & $1.50 \pm 0.96$ & $1.59 \pm 1.16^{\mathrm{a}}$ \\
\hline \multicolumn{2}{|c|}{ Fasting glucose, mg/dl } & $98.1 \pm 20.1$ & $96.9 \pm 19.1$ & $100.2 \pm 21.1$ & $103.7 \pm 26.3^{\mathrm{a}}$ \\
\hline
\end{tabular}

Table 5. Characteristics of CVD risk factors by quartiles of "fruit, vegetables \& dairy" dietary pattern $(\mathrm{X} \pm \mathrm{SD})$

\begin{tabular}{|c|c|c|c|c|c|}
\hline \multirow{2}{*}{\multicolumn{2}{|c|}{ Variable }} & \multicolumn{4}{|c|}{ "Fruit, vegetables \& dairy" DP } \\
\hline & & Q1 & Q2 & Q3 & Q4 \\
\hline \multicolumn{2}{|l|}{ Age, years } & $53.8 \pm 9.9$ & $54.4 \pm 10.2$ & $54.2 \pm 9.9$ & $55.8 \pm 8.7^{a}$ \\
\hline \multicolumn{2}{|c|}{$\begin{array}{l}\text { Systolic blood pressure, } \\
\mathrm{mmHg}\end{array}$} & $146.7 \pm 21.6$ & $145.7 \pm 21.5$ & $143.8 \pm 21.3$ & $144.9 \pm 21.4$ \\
\hline \multicolumn{2}{|c|}{$\begin{array}{l}\text { Diastolic blood pressure, } \\
\mathrm{mmHg}\end{array}$} & $87.5 \pm 11.9$ & $85.6 \pm 11.2$ & $85.4 \pm 11.0$ & $85.3 \pm 11.5^{\mathrm{a}}$ \\
\hline \multirow{2}{*}{$\begin{array}{l}\text { Waist } \\
\text { circumference, } \\
\mathrm{cm}\end{array}$} & Females & $90.2 \pm 15.0$ & $89.8 \pm 13.3$ & $87.8 \pm 13.6$ & $86.9 \pm 12.7^{\mathrm{a}}$ \\
\hline & Males & $100.5 \pm 12.9$ & $99.4 \pm 13.5$ & $98.7 \pm 10.3$ & $96.7 \pm 10.9$ \\
\hline \multirow{2}{*}{ WHR } & Females & $0.85 \pm 0.08$ & $0.85 \pm 0.08$ & $0.84 \pm 0.08$ & $0.83 \pm 0.07^{\mathrm{a}}$ \\
\hline & Males & $0.97 \pm 0.08$ & $0.96 \pm 0.08$ & $0.96 \pm 0.07$ & $0.95 \pm 0.07$ \\
\hline \multicolumn{2}{|l|}{$\mathrm{BMI}, \mathrm{kg} / \mathrm{m}^{2}$} & $28.4 \pm 5.2$ & $28.2 \pm 5.1$ & $28.0 \pm 5.1$ & $28.0 \pm 4.9$ \\
\hline \multicolumn{2}{|l|}{$\mathrm{TC}, \mathrm{mmol} / \mathrm{l}$} & $5.11 \pm 1.07$ & $5.09 \pm 0.98$ & $5.11 \pm 1.01$ & $5.01 \pm 1.01$ \\
\hline \multirow{2}{*}{$\mathrm{HDL}-\mathrm{C}, \mathrm{mmol} / \mathrm{I}$} & Females & $1.55 \pm 0.42$ & $1.58 \pm 0.40$ & $1.64 \pm 0.41$ & $1.61 \pm 0.37^{\mathrm{a}}$ \\
\hline & Males & $1.34 \pm 0.37$ & $1.33 \pm 0.33$ & $1.33 \pm 0.47$ & $1.37 \pm 0.34$ \\
\hline \multicolumn{2}{|l|}{$\mathrm{LDL}-\mathrm{C}, \mathrm{mmol} / \mathrm{I}$} & $2.98 \pm 0.95$ & $2.95 \pm 0.90$ & $2.93 \pm 0.92$ & $2.82 \pm 0.90^{\mathrm{a}}$ \\
\hline \multicolumn{2}{|l|}{$\mathrm{TG}, \mathrm{mmol} / \mathrm{l}$} & $1.58 \pm 1.14$ & $1.44 \pm 0.83$ & $1.41 \pm 0.84$ & $1.41 \pm 0.93^{\mathrm{a}}$ \\
\hline \multicolumn{2}{|c|}{ Fasting glucose, mg/dl } & $102.8 \pm 26.4$ & $100.2 \pm 23.4$ & $97.3 \pm 17.5$ & $98.6 \pm 18.7^{\mathrm{a}}$ \\
\hline
\end{tabular}

Table 6. Characteristics of CVD risk factors by quartiles of "fat \& sugar" dietary pattern $(\mathrm{X} \pm \mathrm{SD})$

\begin{tabular}{|c|c|c|c|c|c|}
\hline \multirow{2}{*}{\multicolumn{2}{|c|}{ Variable }} & \multicolumn{4}{|c|}{ "Fat \& sugar" DP } \\
\hline & & Q1 & Q2 & Q3 & Q4 \\
\hline \multicolumn{2}{|l|}{ Age, years } & $55.3 \pm 8.7$ & $55.0 \pm 9.2$ & $54.1 \pm 9.9$ & $53.7 \pm 11.2^{\mathrm{a}}$ \\
\hline \multicolumn{2}{|c|}{$\begin{array}{l}\text { Systolic blood pressure, } \\
\mathrm{mmHg}\end{array}$} & $147.6 \pm 20.7$ & $146.7 \pm 21.4$ & $144.8 \pm 21.5$ & $142.0 \pm 22.0^{\mathrm{a}}$ \\
\hline \multicolumn{2}{|c|}{$\begin{array}{l}\text { Diastolic blood pressure, } \\
\mathrm{mmHg}\end{array}$} & $86.8 \pm 11.3$ & $86.4 \pm 11.4$ & $85.2 \pm 10.6$ & $85.5 \pm 12.3$ \\
\hline $\begin{array}{l}\text { Waist } \\
\text { circumference, } \\
\mathrm{cm}\end{array}$ & $\begin{array}{l}\text { Females } \\
\text { Males }\end{array}$ & $\begin{array}{l}88.1 \pm 12.5 \\
99.3 \pm 12.7\end{array}$ & $\begin{array}{l}86.7 \pm 12.2 \\
98.7 \pm 11.6\end{array}$ & $\begin{array}{l}88.5 \pm 14.3 \\
97.8 \pm 11.4\end{array}$ & $\begin{array}{c}90.3 \pm 15.0 \\
101.2 \pm 13.3\end{array}$ \\
\hline WHR & $\begin{array}{l}\text { Females } \\
\text { Males }\end{array}$ & $\begin{array}{l}0.83 \pm 0.07 \\
0.96 \pm 0.07\end{array}$ & $\begin{array}{l}0.83 \pm 0.07 \\
0.96 \pm 0.07\end{array}$ & $\begin{array}{l}0.84 \pm 0.08 \\
0.95 \pm 0.08\end{array}$ & $\begin{array}{l}0.86 \pm 0.09^{\mathrm{a}} \\
0.97 \pm 0.07\end{array}$ \\
\hline \multicolumn{2}{|l|}{$\mathrm{BMI}, \mathrm{kg} / \mathrm{m}^{2}$} & $28.6 \pm 5.0$ & $28.0 \pm 4.7$ & $27.9 \pm 5.1$ & $28.1 \pm 5.4$ \\
\hline \multicolumn{2}{|l|}{$\mathrm{TC}, \mathrm{mmol} / \mathrm{l}$} & $4.98 \pm 0.99$ & $5.15 \pm 1.09$ & $4.98 \pm 0.96$ & $5.21 \pm 1.01^{\mathrm{a}}$ \\
\hline $\mathrm{HDL}-\mathrm{C}, \mathrm{mmol} / \mathrm{l}$ & $\begin{array}{l}\text { Females } \\
\text { Males }\end{array}$ & $\begin{array}{l}1.59 \pm 0.40 \\
1.31 \pm 0.33\end{array}$ & $\begin{array}{l}1.63 \pm 0.38 \\
1.33 \pm 0.34\end{array}$ & $\begin{array}{l}1.60 \pm 0.40 \\
1.36 \pm 0.46\end{array}$ & $\begin{array}{l}1.59 \pm 0.41 \\
1.35 \pm 0.38\end{array}$ \\
\hline \multicolumn{2}{|l|}{ LDL-C, mmol/l } & $2.86 \pm 0.90$ & $2.95 \pm 0.93$ & $2.90 \pm 0.89$ & $3.02 \pm 0.95^{\mathrm{a}}$ \\
\hline \multicolumn{2}{|l|}{$\mathrm{TG}, \mathrm{mmol} / \mathrm{l}$} & $1.40 \pm 0.83$ & $1.52 \pm 1.04$ & $1.37 \pm 0.81$ & $1.54 \pm 1.08^{\mathrm{a}}$ \\
\hline \multicolumn{2}{|c|}{ Fasting glucose, mg/dl } & $100.5 \pm 22.2$ & $97.4 \pm 23.5$ & $99.9 \pm 20.8$ & $101.1 \pm 21.3^{\mathrm{a}}$ \\
\hline
\end{tabular}

being older, had significantly lower diastolic blood pressure, LDL-C, TG and fasting glucose level in comparison with the bottom quartile. Women in Q4 had also lower waist circumference and WHR and higher HDL-C than women in Q1. Participants who had higher factor scores for the 'fat \& sugar' DP tended to be younger and have lower systolic blood pressure than those who had lower factor scores for that pattern. However, they also had higher TC, LDL-C, TG, fasting glucose level (overall) and WHR (women).

Comparison of selected nutrients intake across the quartiles of derived dietary patterns is presented in Table 7. Subjects in Q4 of 'traditional' and 'fat \& sugar' DPs had a lower intake of dietary fibre and potassium, and higher intake of SFA and cholesterol in comparison with Q1. Sodium intake was higher in Q4 of "traditional" DP and lower in Q4 of

Table 7. Comparison of selected nutrients intake across the quartiles of dietary patterns $(\mathrm{X} \pm \mathrm{SD})$

\begin{tabular}{lcccccc}
\hline \multirow{2}{*}{ Variable } & \multicolumn{2}{c}{$\begin{array}{c}\text { "Traditional" } \\
\text { DP }\end{array}$} & $\begin{array}{c}c \\
\text { "Fruit, vegetables } \\
\text { \& dairy" DP }\end{array}$ & \multicolumn{2}{c}{ "Fat \& sugar" } \\
DP
\end{tabular}


"fat \& sugar" DP, in comparison with Q1. The 'fat \& sugar' DP was also inversely associated with folate intake. For the 'fruit, vegetables \& dairy' DP, the observed relationships were opposite, except for SFA intake, for which no statically significant difference between Q1 and Q4 was found.

\section{DISCUSSION}

Three dietary patterns identified in the presented study were linked differently with the anthropometric and biochemical risk factors for cardiovascular diseases. Significant differences in the nutritional value between quartiles of derived dietary patterns were also observed.

The 'fruit, vegetables \& dairy' DP was associated with improved lipid profile and anthropometric measures, lower diastolic blood pressure and lower fasting glucose concentration. These results are consistent with other studies in suggesting that the pattern characterized by a high consumption of vegetables, defined in some studies as 'healthy' or 'prudent', may improve cardiovascular risk factors $[16,17]$.

Greater adherence to the 'fruit and vegetables' DP was linked with a higher intake of fibre, folate and potassium. Dietary fibre, as well as other bioactive compounds found in fruits and vegetables, including flavonoids and antioxidant vitamins, may protect against the development of various non-communicable diseases. Although the cardioprotective properties of those substances still remain not fully explained, their intake has been associated with lower risk of CVD development and mortality [18-21]. Also, the consumption of fruit and vegetables itself had a beneficial effect on CVD prevention $[22,23]$.

Since 2016, fruit and vegetables are on the bottom layer of the 'Pyramid of healthy nutrition and physical activity', developed and endorsed by The National Food and Nutrition Institute. According to Polish recommendations, vegetables and fruits may be eaten in unlimited quantities, in proportion of 3:1 [24]. Nonetheless, in the WOBASZ II Study, fruits and vegetables were consumed in recommended doses $(>400 \mathrm{~g}$ per day) only by $50 \%$ of men and $51 \%$ of women [25].

The 'traditional' DP was unfavorably associated with most of the risk factors for CVD presented in this study. The relationships between selected health outcomes and 'traditional' DP identified in different populations strongly depend on the dietary habits of these populations. For instance, in the European Prospective Investigation into Cancer (EPIC) - Netherlands Study, the 'traditional' DP was significantly associated with coronary heart disease (hazard ratio (HR) 1.25 ; 95\% CI: $1.07-1.47$ or 1.29 ; 95\% CI: $1.11-1.50$, depending on the statistical method) [26]. In a cross-sectional study performed in Brazil, the 'traditional' DP had a negative effect on obesity indicators, lipids and fasting plasma glucose [27]. Inversely, the 'traditional Chinese food' pattern was associated with decreased blood pressure and cholesterol level, and the 'Japanese' pattern was related to decreased blood pressure [28, 29].

In the presented study, the 'traditional' DP was characterized by higher consumption of mixed dishes and meat and, as a result, higher intake of SFA, cholesterol and sodium. In other studies, consumption of saturated fatty acids was associated with increased levels of cholesterol in blood [30]. In a meta-analysis of observational studies, no associations were found between SFA intake and the risk of CVD or type 2 diabetes, all-cause mortality and CVD mortality; nonetheless, according to the Scientific Report on the 2015 Dietary Guidelines Advisory Committee, every $1 \%$ of energy intake from SFA replaced with polyunsaturated fatty acids (PUFA), may reduce the incidence of coronary heart disease by $2-3 \%[31,32]$. According to current guidelines, SFA should thus provide less than $10 \%$ of energy and should be replaced by PUFA. Moreover, based on European recommendations, dietary cholesterol intake should not exceed $300 \mathrm{mg}$ per day, but those limitations are not mentioned in the 2015-2020 Dietary Guidelines for Americans [8, 9, 33].

Meat and meat products are common constituents of the habitual Polish diet. Based on the data from 2014, 57\% of Polish men and women consume meat and its products a few times a week and 34\% chose meat every day [34]. In a meta-analysis, processed meat consumption was associated with a $42 \%$ higher risk of coronary heart disease and 19\% higher risk of diabetes, but no association was observed with reference to the red meat intake [35]. However, the relationship between unprocessed red meat consumption and coronary heart disease remains unclear and some authors have reported such an association [36]. The main difference in the nutritional value between red and processed meat was observed with reference to sodium content - an important risk factor for hypertension [37, 38].

The 'fat \& sugar' DP had high factor loadings for solid fats, sugary products and refined grains and was unfavorably associated with the majority of studied risk factors. Surprisingly, greater adherence to the 'fat \& sugar' DP was associated with lower systolic blood pressure. These results were not consistent with the current knowledge on this topic [39]. However, subjects in Q4 of the 'fat \& sugar' DP, despite similar BMI and waist circumference and lower sodium intake, were younger $(\mathrm{P}=0.0006)$ and had higher physical activity level $(\mathrm{P}<0.0001)$ than subjects in $\mathrm{Q} 1$, which may partially explain the observed relationships.

In other studies, high consumption of refined grains, sugar and sweets was related to higher waist circumference, blood pressure, fasting blood glucose level, LDL-C and TG concentration and increased risk of diabetes and coronary heart disease [40-43]. A significant relationship between added sugar consumption and CVD mortality was also observed [44].

Sweets are consumed every day by $19 \%$ and a few times a week by $36 \%$ of Polish men and women [34]. Only 3\% of Polish men and $1 \%$ of Polish women reported consuming the recommended free sugars intakes [45]. Sugar is a source of carbohydrates and energy, but it does not provide any other nutrients. Refined grain products contain less dietary fibre, vitamins and minerals than whole grains and they have higher glycemic index [14, 46]. Moreover, various sweetened desserts are also a source of invisible fat containing not recommended fatty acids $[8,9]$.

Is this dietary patterns analysis a better tool for evaluating the associations between diet and health, than analysis concerning only single dietary components? The effect of single food products or nutrients on health outcomes may sometimes be too small to investigate and, what is more, individual nutrients may intercorrelate with each other, which makes their separate properties difficult to detect. That is why studies concerning single nutrients or foods often fail to find significant relationships with health outcomes, while 
the approach that includes the cumulative effect of various components of the diet, may lead to another look at these associations [47].

Following that line of reasoning, the beneficial effects of certain food products and nutrients (e.g. in particular vegetables), may be supported by the properties of the other components of the dietary pattern, including other fruits and vegetables. Based on the dietary patterns analysis, it is known that people who eat a lot of vegetables, usually also consume a lot of fruits and whole grains, and generally have healthier dietary habits. On the other hand, the inconclusive and often contradictory results of some studies, even if they are adjusted for known confounding factors, may result from the overall effect of the entire diet, which is the confounder itself.

Unhealthy DPs, associated mainly with high consumption of processed meat, solid fats, refined grains and sugar, may be thus an important cardiovascular risk factor. That is why current guidelines recommend consuming a healthy eating pattern, characterized by a variety of vegetables, fruit, grains, low-fat or fat-free dairy, protein foods and oils, in order to reduce cardiovascular risk factors $[9,48]$. Greater adherence to a healthy DPs may play a key role in the prevention of cardiovascular diseases and may be more important than only the avoidance of products typical for unhealthy DPs [49].

\section{CONCLUSIONS}

Dietary pattern analysis is a useful tool to assess the association between habitual dietary habits and health because it takes into account the complexity of the diet. In this study, greater adherence to the 'fruit, vegetables \& dairy' DP was favourably associated with biochemical and anthropometric CVD risk factors. For the 'traditional' and 'fat \& sugar' DPs, the observed relationships were the opposite. The consumption of fruit, vegetables and low-fat dairy products was also linked with higher nutritional value of the diet in comparison with a high intake of meat and meat products, sugar and fats. According to the results of this study, the 'fruit, vegetables \& dairy' DP may be recommended for the prevention of cardiovascular diseases among the inhabitants of Lower Silesia.

\section{REFERENCES}

1. Townsend N, Wilson L, Bhatnagar P, Wickramasinghe K, Rayner M, Nichols M. Cardiovascular disease in Europe: epidemiological update 2016. Eur Heart J. 2016; 37(42): 3232-3245.

2. Mahmood SS, Levy D, Vasan RS, Wang TJ. The Framingham Heart Study and the Epidemiology of Cardiovascular Diseases: A Historical Perspective. Lancet. 2014; 383(9921): 999-1008.

3. ZdrojewskiT, Bandosz P, GaciongZ, WyrzykowskiB. Rozpowszechnienie czynników ryzyka chorób układu sercowo-naczyniowego w Polsce w 2011 r. Zakres wieku 18-79 lat. XV Międzynarodowy Kongres Polskiego Towarzystwa Kardiologicznego, Wrocław, 6-8 October 2011.

4. Hu T, Mills KT, Yao L, Demanelis K, Eloustaz M, Yancy WS, et al. Effects of Low-Carbohydrate Diets Versus Low-Fat Diets on Metabolic Risk Factors: A Meta-Analysis of Randomized Controlled Clinical Trials. Am J Epidemiol. 2012; 176(Suppl 7): S44-S54.

5. Keys A, Menotti A, Karvonen MJ, Aravanis C, Blackburn H, Buzina $\mathrm{R}$, et al. The diet and 15-year death rate in the seven countries study. Am J Epidemiol. 1986; 124(6): 903-915.

6. Grosso G, Mistretta A, Frigiola A, Gruttadauria S, Biondi A, Basile F, et al. Mediterranean diet and cardiovascular risk factors: a systematic review. Crit Rev Food Sci Nutr. 2014; 54(5): 593-610.
7. Anand SS, Hawkes C, de Souza RJ, Mente A, Dehghan M, Nugent R, et al. Food Consumption and its impact on Cardiovascular Disease: Importance of Solutions focused on the globalized food system: A Report from the Workshop convened by the World Heart Federation. J Am Coll Cardiol. 2015; 66(14): 1590-1614.

8. Catapano AL, Graham I, De Backer G, Wiklund O, Chapman MJ, Drexel H, et al. 2016 ESC/EAS Guidelines for the Management of Dyslipidaemias. Eur Heart J. 2016; 37(39): 2999-3058.

9. U.S. Department of Health and Human Services and U.S. Department of Agriculture. 2015-2020 Dietary Guidelines for Americans 8th ed. http://health.gov/dietaryguidelines/2015/guidelines/ (access: 2017.04.10)

10. Corsi DJ, Subramanian SV, Chow CK, McKee M, Chifamba J, Dagenais $\mathrm{G}$, et al. Prospective Urban Rural Epidemiology (PURE) study: Baseline characteristics of the household sample and comparative analyses with national data in 17 countries. Am Heart J. 2013; 166(4): 636-646.e4.

11. Miller V, Yusuf S, Chow CK, Dehghan M, Corsi DJ, Lock K, et al. Availability, affordability, and consumption of fruits and vegetables in 18 countries across income levels: findings from the Prospective Urban Rural Epidemiology (PURE) study. Lancet Glob Health. 2016; 4(10): e695-703.

12. Dehghan M, Ilow R, Zatonska K, Szuba A, Zhang X, Mente A, et al. Development, reproducibility and validity of the food frequency questionnaire in the Poland arm of the Prospective Urban and Rural Epidemiological (PURE) study. J Hum Nutr Diet. 2012; 25(3): 225-232.

13. Szponar L, Wolnicka K, Rychlik E. Album of photographs of food products and dishes. Warsaw, The Food and Nutrition Institute, 2000.

14. Kunachowicz H, Nadolna I, Iwanow K, Przygoda B. Polish Food Composition Tables. Warsaw, PZWL, 2005.

15. US Department of Agriculture, Agricultural Research Service, Nutrient Data Laboratory. USDA National Nutrient Database for Standard Reference, Release 24: 2011. http://www.ars.usda.gov/ba/bhnrc/ndl (access 2011.10.09).

16. Li P, Zhang M, Zhu Y, Liu W, Zhang Y, Gao Y, et al. Dietary patterns and changes in cardiovascular risk factors in apparently healthy Chinese women: a longitudinal study. J Clin Biochem Nutr. 2016; 58(3): 232-239.

17. Sauvageot N, Leite S, Alkerwi A, Sisanni L, Zannad F, Saverio S, et al. Association of Empirically Derived Dietary Patterns with Cardiovascular Risk Factors: A Comparison of PCA and RRR Methods. PLoS One. 2016; 11(8): e0161298.

18. Threapleton DE, Greenwood DC, Evans CEL, Cleghorn CL, Nykjaer C, Woodhead C, et al. Dietary fibre intake and risk of cardiovascular disease: systematic review and meta-analysis. BMJ. 2013; 347: f6879.

19. McCullough ML, Peterson JJ, Patel R, Jacques PF, Shah R, Dwyer JT. Flavonoid intake and cardiovascular disease mortality in a prospective cohort of US adults. Am J Clin Nutr. 2012; 95(2): 454-464.

20. Ponzo V, Goitre I, Fadda M, Gambino R, De Francesco A, Soldati L, et al. Dietary flavonoid intake and cardiovascular risk: a populationbased cohort study. J Transl Med. 2015; 13: 218.

21. Stepaniak U, Micek A, Grosso G, Stefler D, Topor-Madry R, Kubinova $\mathrm{R}$, et al. Antioxidant vitamin intake and mortality in three Central and Eastern European urban populations: the HAPIEE study. Eur J Nutr. 2016; 55(2): 547-560.

22. Yu D, Zhang X, Gao YT, Li H, Yang G, Huang J, et al. Fruit and Vegetable Intake and Risk of Coronary Heart Disease: Results from Prospective Cohort Studies of Chinese Adults in Shanghai. Br J Med. 2014; 111(2): 353-362.

23. Lamb MJE, Griffin SJ, Sharp SJ, Cooper AJM. Fruit and vegetable intake and cardiovascular risk factors in people with newly diagnosed type 2 diabetes. Eur J Clin Nutr. 2017; 71(1): 115-121.

24. National Food and Nutrition Institute. Healthy Nutrition and Physical Activity Pyramid 2016. http://www.izz.waw.pl/pl/zasady-prawidowegoywienia\#g (access 2017.04.15)

25. Waśkiewicz A, Szcześniewska D, Szostak-Węgierek D, Kwaśniewska M, Pająk A, Stepaniak U, et al. Are dietary habits of the Polish population consistent with the recommendations for prevention of cardiovascular disease? - WOBASZ II project. Kardiol Pol. 2016; 74(9): 969-977.

26. Biesbroek S, van der A DL, Brosens MC, Beulens JW, Verschuren WM, van der Schouw YT, et al. Identifying cardiovascular risk factor-related dietary patterns with reduced rank regression and random forest in the EPIC-NL cohort. Am J Clin Nutr. 2015; 102(1): 146-154.

27. Castro MA, Baltar VT, Marchioni DM, Fisberg RM. Examining associations between dietary patterns and metabolic CVD risk factors: a novel use of structural equation modelling. Br J Nutr. 2016; 115(9): 1586-1597.

28. Sun J, Buys N, Shen S. Dietary Patterns and Cardiovascular DiseaseRelated Risks in Chinese Older Adults. Front Public Health. 2013; 1: 48. 
29. Niu K, Momma H, Kobayashi Y, Guan L, Chujo M, Otomo A et al. The traditional Japanese dietary pattern and longitudinal changes in cardiovascular disease risk factors in apparently healthy Japanese adults. Eur J Nutr. 2016; 55(1): 267-279.

30. Mensink RP, Zock PL, Kester AD, Katan MB. Effects of dietary fatty acids and carbohydrates on the ratio of serum total to HDL cholestero and on serum lipids and apolipoproteins: a meta-analysis of 60 controlled trials. Am J Clin Nutr. 2003; 77(5): 1146-1155.

31. De Souza RJ, Mente A, Maroleanu A, Cozma Adrian I, Ha Vanessa, Kishibe T, et al. Intake of saturated and trans unsaturated fatty acids and risk of all cause mortality, cardiovascular disease, and type 2 diabetes: systematic review and meta-analysis of observational studies. BMJ. 2015; 351: h3978

32. US Dietary Guidelines Advisory Committee. Scientific report of the 2015 dietary guidelines advisory committee. 2015. https://health.gov/ dietaryguidelines/2015-scientific-report/PDFs/Scientific-Reportof-the-2015-Dietary-Guidelines-Advisory-Committee.pdf (access 2017.07.31)

33. Piepoli MF, Hoes AW, Agewall S, Albus C, Brotons C, Catapano AL, et al. 2016 European Guidelines on cardiovascular disease prevention in clinical practice: The Sixth Joint Task Force of the European Society of Cardiology and Other Societies on Cardiovascular Disease Prevention in Clinical Practice (constituted by representatives of 10 societies and by invited experts). Developed with the special contribution of the European Association for Cardiovascular Prevention \& Rehabilitation (EACPR). Eur Heart J. 2016; 37(29): 2315-2381.

34. Centrum Badania Opinii Społecznej. Zachowania Żywieniowe Polaków. http://www.cbos.pl/SPISKOM.POL/2014/K_115_14.PDF (access 2017.03.21)

35. Micha R, Wallace SK, Mozaffarian D. Red and processed meat consumption and risk of incident coronary heart disease, stroke, and diabetes: A systematic review and meta-analysis. Circulation. 2010; 121: 2271-2283.

36. Pan A, Sun Q, Bernstein AM, Schulze MB, Manson JE, Stampfer MJ, et al. Red meat consumption and mortality: results from 2 prospective cohort studies. Arch Intern Med. 2012; 172(7): 555-563.

37. Zhang Z, Cogswell ME, Gillespie C, Fang J, Loustalot F, Dai S, et al. Association between Usual Sodium and Potassium Intake and Blood Pressure and Hypertension among U.S. Adults: NHANES 2005-2010. Zhang W, ed. PLoS One. 2013; 8(10): e75289.

38. Yang Q, Liu T, Kuklina EV, Flanders WD, Hong Y, Gillespie C, et al. Sodium and potassium intake and mortality among US adults: prospective data from the Third National Health and Nutrition Examination Survey. Arch Intern Med. 2011; 171(13): 1183-1191.

39. Ndanuko RN, Tapsell LC, Charlton KE, Neale EP, Batterham MJ. Dietary Patterns and Blood Pressure in Adults: A Systematic Review and Meta-Analysis of Randomized Controlled Trials. Adv Nutr. 2016; 7: 76-89.

40. Eilat-Adar S, Mete M, Fretts A, Fabsitz RR, Handeland V, Lee ET, et al. Dietary Patterns and Their Association with Cardiovascular Risk Factors in a Population Undergoing Lifestyle Changes: The Strong Heart Study. Nutr Metam Cardiovasc Dis. 2013; 23(6): 528-535.

41. Schulze MB, Hoffmann K, Manson JE, Willett WC, Meigs JB, Weikert $\mathrm{C}$, et al. Dietary pattern, inflammation, and incidence of type 2 diabetes in women. Am J Clin Nutr. 2005; 82(3): 675-715.

42. Naja F, Hwalla N, Itani L, Salem M, Azar ST, Zeidan MN, et al. Dietary patterns and odds of Type 2 diabetes in Beirut, Lebanon: a case-control study. Nutr Metab. 2012; 9(1): 111.

43. Yu D, Shu X-O, Li H, Xiang YB, Yang G, Gao YT, et al. Dietary Carbohydrates, Refined Grains, Glycemic Load, and Risk of Coronary Heart Disease in Chinese Adults. Am J Epidemiol. 2013; 178(10): 1542-1549.

44. Yang Q, Zhang Z, Gregg EW, Flanders WD, Merritt R, Hu FB. Added sugar intake and cardiovascular diseases mortality among US adults. JAMA Intern Med. 2014; 174(4): 516-524.

45. Boylan S, Welch A, Pikhart H, Malyutina S, Pająk A, Kubinova R, et al. Dietary habits in three Central and Eastern European countries: the HAPIEE study. BMC Public Health. 2009; 9: 439.

46. Foster-Powell K, Holt SH, Brand-Miller JC. International table of glycemic index and glycemic load values: 2002. Am J Clin Nutr. 2002; 76(1): 5-56.

47. Hu FB. Dietary pattern analysis: a new direction in nutritional epidemiology. Curr Opin Lipidol. 2002; 13(1): 3-9.

48. Van Horn L, Carson JA, Appel LJ, Burke LE, Economos C, Karmally W, et al. Recommended Dietary Pattern to Achieve Adherence to the American Heart Association/American College of Cardiology (AHA/ ACC) Guidelines: A Scientific Statement From the American Heart Association. Circulation. 2016; 134(22): e505-e529.

49. Stewart RA, Wallentin L, Benatar J, Danchin N, Hagström E, Held C, et al. Dietary patterns and the risk of major adverse cardiovascular events in a global study of high-risk patients with stable coronary heart disease. Eur Heart J. 2016; 37(25): 1993-2001. 